\title{
Effect of Solution Annealing on Alpha Prime Martensitic Microstructure of Cold Rolled AISI316L Stainless Steel
}

ISSN: 2578-0255

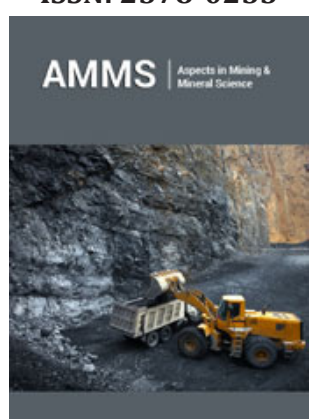

*Corresponding author: Yong-Soo Kim, Department of Nuclear Engineering, Hanyang university, Korea

Submission: 眥 November 14, 2019

Published: 䍞 November 25, 2019

Volume 4 - Issue 1

How to cite this article: Y S Kim, D J Lee , Yu Jin Kang, Sung Joon P. Effect of Solution Annealing on Alpha Prime Martensitic Microstructure of Cold Rolled AISI316L Stainless Steel. Aspects Min Miner Sci.4(1) AMMS.000580.2019.

DOI: 10.31031/AMMS.2019.04.000580

Copyright@ Yong-Soo Kim, This article is distributed under the terms of the Creative Commons Attribution 4.0 International License, which permits unrestricted use and redistribution provided that the original author and source are credited.

\author{
Y S Kim¹*, D J Lee1, Yu Jin Kang and Sung Joon Pak ${ }^{2}$ \\ ${ }^{1}$ Department of Nuclear Engineering, Hanyang university, Korea \\ ${ }^{2}$ KITECH, Korea
}

\begin{abstract}
The effects of solution annealing on alpha prime $(\alpha)$ martensitic microstructure of cold rolled AISI316L austenitic stainless steel have been studied using XRD and corrosion analysis technique. Based on the good compatibility to high temperature water environment, AISI316L austenitic stainless steel is widely used for internal structural materials of light water reactors. However, recently, Stress Corrosion Cracking (SCC) was detected in the stainless steels for the applications in some commercial PWR plants. In this paper, the root cause of the SCC and its countermeasure are discussed on the basis of martensitic transformation in relationship with solution annealing and alpha martensitic microstructure. The martensitic contents of cold rolled AISI316L stainless steel decreased as solution annealing time increased with higher temperature. The mode of martensitic content change was deeply related to the solution annealing time and temperature. Therefore, it is considered that solution annealing and alpha prime martensitic microstructure play an important role in SCC resistance of cold rolled AISI316L. This leads us to conclude that the SCC resistance of AISI316L can be enhanced by the optimal solution annealing.
\end{abstract}

Keywords: Alpha prime martensitic phase; Solution annealing; Stress corrosion cracking; AISI316L; Austenitic stainless steels

\section{Introduction}

Intergranular attack in austenitic stainless steels has been of great interests and investigated for about one century [1]. Specifically, intergranular corrosion and sensitization have been focused in relation to chromium depletion at the grain boundaries [2-8]. Austenitic stainless steels have been commonly used for internal structural materials of light water reactors and heavy water reactors, due to its good compatibility to high temperature water environment. However, in early 1970s, intergranular cracking (IGC) was observed in the $25 \% \mathrm{Cr}-20 \% \mathrm{Ni}$ austenitic stainless steel of the parts of fuel assembly for steam generating heavy water reactor [9] and the $\mathrm{Cr}$ depletion and $\mathrm{Ni}$, Si enrichment were detected near the grain boundaries of this material. The material flow during plastic deformation process considerably affects the product quality-its structure and properties, the process efficiency and the deformation force amplitude. The changes of basic properties (resistance and plasticity) of the deformed material present importance to ensure the final mechanical characteristics of the parts for an appropriate behavior in working condition [10-11]. The increase of $\alpha(110)$ martensitic structure by martensitic transformation induced by plastic deformation causes a change in physical properties of austenitic stainless steels. The martensitic transformation is expected to change by stress states. Even though stainless steels are known having a good resistance to general corrosion because they form a thin chromium rich passive surface film, they are susceptible to localized corrosion attack such as pitting, intergranular corrosion, and stress corrosion cracking [12-17]. We study the effects of solution annealing and load reversals on $\alpha$ martensitic phase of cold rolled AISI316L. The SCC resistance of AISI316L can be enhanced by the solution annealing. The advantages of using solution annealing indicate the new contributions about SCC resistance since there are many papers related to the martensitic transformation is expected to change by stress states. 


\section{Experimental Procedure}

The material used in our study was an AISI316L austenitic stainless steel with its chemical composition shown in Table 1. AISI316L samples were cold rolled as $10 \%$ and $20 \%$, producing average grain size of $50 \mu \mathrm{m}$. Residual martensitic contents were detected using XRD after solution annealing. Table 2 shows the specimen conditions used for the solution annealing tests. Fourteen distinct specimens numbered from 1 to 14 were then analyzed for their martensitic intensity. Fourteen specimens numbered from 1 to 14 were then analyzed using XRD and corrosion tested. The centers of specimen surfaces exposed to the XRD test were observed by an optical microscope system (OLYMPUS BX51M), scanning electron microscope (NOVA NANO SEM) and transmission electron microscope (JEM 2000F).

Table 1: Chemical composition of the AISI316L austenitic stainless steel (wt. \%).

\begin{tabular}{|c|c|c|}
\hline Elements & Measured & AISI316L \\
\hline $\mathrm{C}$ & 0.011 & $0.03 \mathrm{max}$ \\
\hline $\mathrm{Si}$ & 0.34 & $0.75 \mathrm{max}$ \\
\hline $\mathrm{Mn}$ & 0.558 & $2.00 \mathrm{max}$ \\
\hline $\mathrm{P}$ & 0.0296 & $0.045 \mathrm{max}$ \\
\hline $\mathrm{S}$ & 0.0017 & $0.030 \mathrm{max}$ \\
\hline $\mathrm{Ni}$ & 12.222 & $10.00 \sim 14.00$ \\
\hline $\mathrm{Cr}$ & 17.612 & $16.00 \sim 18.00$ \\
\hline $\mathrm{Mo}$ & 2.054 & $2 \sim 3$ \\
\hline $\mathrm{Co}$ & 0.098 & $0.100 \mathrm{max}$ \\
\hline
\end{tabular}

Table 2: Conditions of specimens for the solution annealing tests.

\begin{tabular}{|c|c|c|c|}
\hline Specimen No. & Cold Rolling (\%) & Annealing Time (min) & Annealing Temperature \\
\hline 1 & - & - & - \\
\hline 2 & 10 & 10 & 1050 \\
\hline 3 & 10 & 20 & 1050 \\
\hline 4 & 10 & 30 & 1050 \\
\hline 5 & 10 & 10 & 1075 \\
\hline 6 & 10 & 20 & 1075 \\
\hline 7 & 10 & 30 & 1075 \\
\hline 8 & 10 & 10 & 1050 \\
\hline 10 & 20 & 20 & 1050 \\
\hline 11 & 20 & 30 & 1050 \\
\hline 12 & 20 & 10 & 1075 \\
\hline 14 & 20 & 20 & 1075 \\
\hline
\end{tabular}

\section{Result and Discussion}

We evaluate solution annealing of cold rolled specimens. Figure 1 shows the martensitic phase measurement results for AISI316L specimens. It is revealed that the martensitic phase properties depend only on solution annealing time, possibly due to microstructure transfer processes at the grain boundaries. As shown in Figure 1, the similarity of both properties for different specimens also indicates that cold rolling mechanism is influential for the annealing time of all specimens. The intensity ratio as shown in Figure 1 exhibits a flat line that decreases from the cold rolled specimens to the low annealing temperature specimens. We employ the salt technique in order to quantitatively evaluate the intergranular corrosion resistance of the AISI316L. Corrosion occurs more at all grain boundaries and this shows the susceptibility to corrosion as cold rolled. The results show that the annealing treatment increases the intergranular corrosion resistance of the specimens. The salt tests confirm the other results, showing the susceptibility to intergranular corrosion $[3,17]$. 

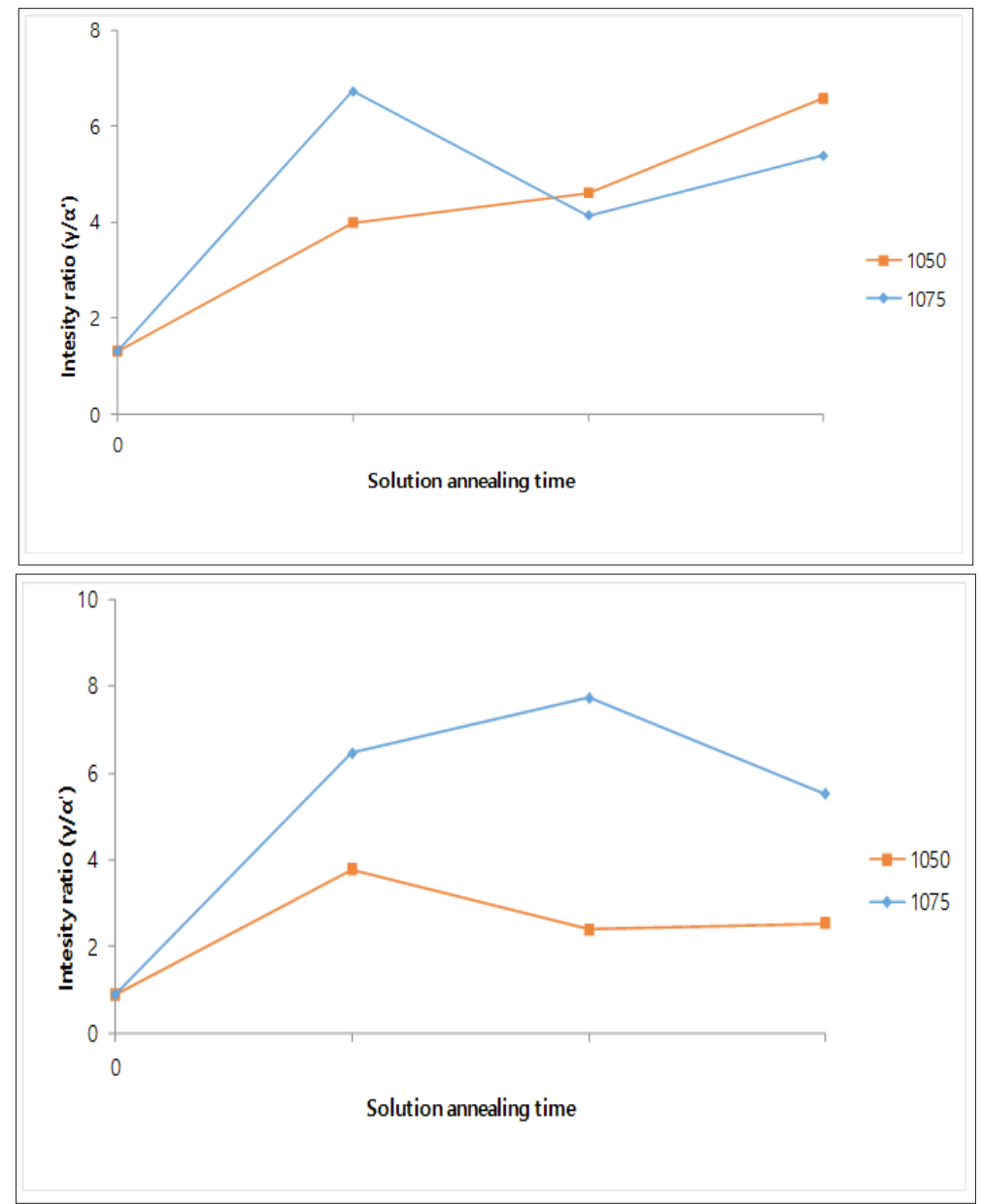

Figure 1: XRD properties measurement in relationship with intensity ratio (gamma/alpha prime face) for AISI316L specimens:

$10 \%$ cold rolled specimens

$20 \%$ cold rolled specimens

\section{Conclusion}

Based on the good compatibility to high temperature water environment, AISI316L austenitic stainless steel is widely used for internal structural materials of light water reactors. However, recently, intergranular cracking was detected in the stainless steels for the applications in some commercial PWR plants. The susceptibility to intergranular corrosion of the cold rolled AISI316L stainless steel was highly affected by alpha martensite and cold rolling. The resistance to intergranular corrosion increased by more than a factor of two when the optimal solution annealing is applied. The corrosion characteristics of the test specimens may be attributed to the transfer of microstructures. Consequently, the corrosion resistance of AISI316L can be improved with the optimal annealing time and temperature and decreasing IGC in AISI316L stainless steel.

\section{Acknowledgment}

This work was supported by KHNP (www.khnp.co.kr). [Project Name: K-CLOUD].

\section{References}

1. Padilha A, Plaut R, Rios P (2007) Steel heat treatment. ( $2^{\text {nd }}$ edn), CRC Press, Florida, USA, p. 695.

2. Zingales A, Quartarone G, Moretti G (1985) Sigma phase intergranular corrosion effects in austenitic welds containing ferrite. Corrosion 41(3): 136-141.

3. Muraleedharan P, Gnanamoorthy JB, Rodriguez P (1996) Comparative study: Degree of sensitization and intergranular stress corrosion cracking susceptibility of type 304 stainless steel. Corrosion 52(10): 790-800.

4. Chattoraj I, Bhattamishra A, Jana S, Das S, Chakraborty S, De P (1996) The association of potentio kinetic reactivation and electrochemical pitting tests on a nitrogen bearing $19 \mathrm{Cr}-17 \mathrm{Mn}$ steel with its thermal history. Corr Sci 38(6): 957-969.

5. Shankar P, Shaikh H, Sivakumar S, Venugopal S, Sundararaman D, et al. (1999) Effect of thermal aging on the room temperature tensile properties of AISI type 316LN stainless steel. J Nucl Mater 264(1-2): 2934.

6. Sahlaoui H, Makhlouf K, Sidhom H, Philibert J (2004) Effects of ageing conditions on the precipitates evolution, chromium depletion and intergranular corrosion susceptibility of AISI 316L: experimental and modeling results. Mater Sci Eng A 372(1-2): 98-108. 
7. Stonawska Z, Svoboda M, Sozanska M, Kristková M, Sojka J, et al. (2006) Structural analysis and intergranular corrosion tests of AISI 316L steel. J Microsc 224(1): 62-64.

8. Terada M, Saiki M, Costa I, Padilha A (2006) Microstructure and intergranular corrosion of the austenitic stainless steel 1.4970 . J Nucl Mater 358(1): 40-46.

9. Scott PM, Foot W, Goldsmith LA, Dumbill S, Williams TM, et al. (1987) NEA/UNIPEDE specialists Mtg. on life-limiting \& regulatory aspects of core internals and pressure vessels, Stockholm, Sweden.

10. Sanga M, Yukawa N, Ishikawa T (1997) International symposium on designing, Japan.

11. Gabrielson P, Schedin E, Ekstrand G (1999) Advanced Technology of Plasticity 2: 1383-1388.

12. NN Contract 248/1999 (1999) Research on corrosion behaviour of heat exchanger plates from Apaterm SA. Galati, Romania.
13. Chandra K, Kain V, Ganesh P (2008) Controlling end-grain corrosion of austenitic stainless steels. J of Mater Eng and Performance 17(1): 115122 .

14. Solomon N, Solomon I (2010) Material flow pattern and structure evaluation during extrusion of 2024 Aluminum alloy. UPB Sci Bull Series B 72(2): 215-226.

15. Kim K, Ju H, Moon Y, Hong J, Pak S (2016) Metal Trans 47: 4979-4982.

16. Kim K, Lim S, Pak S (2015) Effects of the solid solution heat treatment on the corrosion resistance property of SSC13 cast alloy SSC13. Corrosion Science and Technology 14(2): 93-98.

17. Solomon N, Solomon I (2017) Effect of deformation-induced phase transformation on AISI 316 stainless steel corrosion resistance. Engineering Failure Analysis 79: 865-875. 